\title{
House dust mite allergen in bedroom floor dust and respiratory health of children with asthmatic symptoms
}

\author{
J.P. Zock*, B. Brunekreef*, A.A.J.M. Hazebroek-Kampschreur**, C.W. Roosjen
}

\begin{abstract}
House dust mite allergen in bedroom floor dust and respiratory health of children with asthmatic symptoms. J.P. Zock, B. Brunekreef, A.A.J.M. Hazebroek-Kampschreur, C.W. Roosjen. CERS Journals Ltd 1994.

ABSTRACT: The purpose of this study was to investigate the effects of house dust mite allergen in bedroom floor dust on respiratory health of children with asthmatic symptoms.

Two hundred and twenty eight school children with reported attacks of shortness of breath with wheezing in the past year and/or with doctor-diagnosed asthma, were included in the study. Data on home characteristics, both past and present, were obtained. These included data on allergen avoidance measures because of the child's respiratory health. Dust samples were taken from the child's bedroom floor, and the allergen Der $p$ I of the house dust mite Dermatophagoides pteronyssionus was measured. Health diaries were kept over 4 weeks. Acute respiratory symptoms and medication usage were recorded daily. Peak expiratory flow (PEF) was measured using Mini-Wright peak flow meters three times daily.

Levels of Der $p$ I in dust from carpeted floors were significantly higher than in dust from smooth floors. We found a positive relationship of Der $p$ I levels, in floor dust collected from carpeted floors, with PEF-variability and also with the prevalence of wheeze, shortness of breath, and attacks of shortness of breath with wheezing during the observation period. The effects on peak flow variability was larger in children allergic to house dust than in children not allergic to house dust. Peak flow variability was significantly increased at exposure levels well below $10,000 \mathrm{ng}$

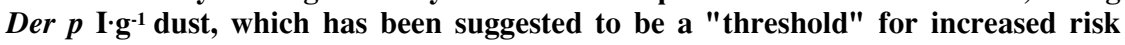
symptoms among sensitized asthmatics.

We conclude that exposure to high Der $p$ I levels in the bedroom may be an important risk factor for the severity of asthmatic symptoms in sensitized children. Eur Respir J., 1994, 7, 1254-1259.
\end{abstract}

*Dept of Epidemiology and Public Health, University of Wageningen, The Netherlands. *** Municipal Health Dept of Rotterdam, The Netherlands. ${ }^{\top}$ Regional Health Dept, Ede, The Netherlands.

\section{Correspondence: B. Brunekreef}

University of Wageningen

Dept of Epidemiology and Public Health P.O. Box 238

6700 AE Wageningen

The Netherlands

Keywords: Allergen avoidance measures childhood asthma

house dust mite

peak flow

Received: June 161993

Accepted after revision March 291994
Exposure to house dust mite allergens is well recognised as an important risk factor for the development of asthma [1-3]. High levels of mite allergens in the house increase the risk of sensitization in atopic children [1, $4,5]$, as well as the occurrence of acute asthmatic symptoms [3]. Dermatophagoides pteronyssinus is the predominant house dust mite in Western Europe. Since the discovery of the importance of allergens from these mites in 1964 [6], many studies have focused on the number of mites and, with the availability of assays for specific mite allergens, also on allergen levels in homes [5, 7-11].

There have been a few studies on the effects of exposure to mite allergens on the severity of asthma. VERVLOET et al. [12] found positive relationships between the mite allergen concentration in mattress dust and the number of asthma attacks and the medical treatment level, in 49 mite-allergic asthmatic patients. Zock et al. [13] found positive relationships of allergen level in mattress dust with peak flow variability and with frequency of wheezing in 96 asthmatic children.
Provisional standards for mite allergen levels have been recommended. A threshold level of 2,000 ng.g-1 of settled house dust has been suggested to be a risk factor for sensitization, whereas $10,000 \mathrm{ng} \cdot \mathrm{g}^{-1}$ has been put forward as a threshold level for acute asthma in sensitized subjects [3].

Our present objective was to study the relationship between Der $p$ I levels in bedroom floor dust and peak flow variability, respiratory symptoms and medication intake in children with asthmatic symptoms.

\section{Subjects and methods}

\section{Study population}

In August/September 1990, parent-administered questionnaires were distributed among all 11,184 pupils (aged 4-12 yrs) from 50 primary schools in The Netherlands, to assess chronic respiratory symptoms. Thirty schools 
were located in an urban area and twenty in a rural area. The response rate to this questionnaire was $78 \%$.

Children were selected who answered positively to one or more of the following questions:

1) $\operatorname{attack}(\mathrm{s})$ of shortness of breath with wheezing during the past year;

2) "asthma" diagnosed by a physician in the past;

3) treated for "asthma" by a lung physician during the past year.

In 657 out of 8,761 children, one or more of these questions were answered positively (7.5\%). A random sample of these selected children was taken, and the parents were asked to join the study. Of those approached, 264 (85\% of the sample) were willing to participate in the study. No further clinical assessment was made on the children.

\section{Characterisation of the homes}

The homes of the children were visited once. One of the parents was interviewed to obtain data on home characteristics both past and present (during the child's life). Characteristics were floor carpeting, mattress and bedding, pet keeping, smoking habits, damp stains and mould spots, and water heating equipment. Information on allergen avoidance measures, taken because of the child's respiratory disease, was also obtained.

A dust sample was taken by one of the investigators from the bedroom floor next to the child's bed, according to an internationally standardised protocol [3]. Dust from $2 \mathrm{~m}^{2}$ floor surface was sampled using a vacuum cleaner connected to the ALK dust collecting device (Copenhagen, Denmark) with a paper filter. The sampling time was 2 minutes per $\mathrm{m}^{2}$. To avoid seasonal effects, all dust samples were taken within two months (October and November 1990). Samples were taken by a total of four trained investigators using three identical vacuum cleaners. About $200 \mathrm{mg}$ of dust from each filter was extracted in $2 \mathrm{ml} 0.125 \mathrm{M}$ ammoniumhydrogencarbonate, by agitating for two hours, followed by centrifuging at $1000 \mathrm{~g}$ for $15 \mathrm{~min}$. The extracts were analysed for Der $p$ I content by an enzyme immunoassay, following procedures previously described [7]. Concentrations were expressed in $\mathrm{ng}^{\circ} \mathrm{g}^{-1}$ dust.

\section{Health outcome}

Questions on respiratory symptoms and allergies of the child were included at the interview. To investigate the day-to-day variations in respiratory health of the subjects, a diary was used. During the home visit, the parents were instructed how to keep records of respiratory symptoms, medication intake and peak expiratory flow (PEF) for a four week period in the autumn of 1990. The symptoms were "cough", "shortness of breath", "wheezing", "attacks of shortness of breath with wheezing", and "woken up with respiratory symptoms". These symptoms were recorded daily on a scale as 0 (not), 1 (slight), 2 (moderate) or 3 (severe). Medication intake was recorded as number of puffs or capsules for each medicine. Peak expiratory flow (PEF) was measured using Mini-Wright peak flow meters three times a day: in the morning (before intake of medication, if any), in the afternoon (immediately after school) and in the evening (before dinner and before medication intake). On each occasion, three attempts were performed, and the highest of these three was recorded in the diary. Completing the diary took place in the period October-December 1990.

The medication intake was classified into two categories: 1) bronchodilators, and 2) other "maintenance" medication (antihistamines, inhaled steroids and cromoglygates). For each day, the peak flow variability (PV) was calculated. The daily amplitude (maximum minus the minimum PEF) was divided by the day's mean PEF for each child on each day, resulting in a dimensionless indicator of PV: the AMP/MEAN [14]. A high PV may indicate bronchial responsiveness.

For each subject, the symptoms, medication usage and peak flow variability were averaged over all 28 days of the study period.

\section{Statistical analysis}

Data were analysed using SAS package [15]. The distribution of the Der $p$ I concentrations was found to be right-skewed, therefore the ln-transformed values were used in analyses. Differences in allergen levels and in health outcome variables between subgroups were compared by Student's unpaired t-test. We divided the children into those with carpeted and uncarpeted bedroom floors, respectively, in some of the analyses because removal of carpets from bedrooms is a frequently practiced allergen avoidance measure in the Netherlands. The relationships between health outcome variables and exposure variables were evaluated with multiple linear regression. Potential confounders were age of subject, gender, socio-economic status, area (urban/rural), floor carpeting, pet keeping, smoking habits, damp stains and mould spots, and presence of unvented water heaters. Odds ratios for high peak flow variability were calculated to investigate the effect of using different cut-off points for Der $p$ I exposure.

\section{Results}

The study population consisted of 228 children with data from the diary, the interview and dust analysis. Population characteristics are shown in table 1. The mean age was 7.5 yrs (SD 2.2).

A considerable number of allergen avoidance measures had been taken during the child's life. Removing carpets had been one of the most frequently applied measures. In 58 homes the inhabitants had changed the living-room floor cover, and in 77 homes the inhabitants had changed the bedroom floor cover, in response to the child's respiratory symptoms. The new living room floors (observed during the survey) were, in $57 \%$ of the cases 
Table 1. - Population characteristics

\begin{tabular}{lcc}
\hline & n/total n & $\%$ \\
\hline Gender (male) & $139 / 228$ & 61 \\
Area (urban) & $127 / 228$ & 56 \\
Doctor-diagnosed asthma & $125 / 217$ & 58 \\
Allergic to house dust* & $95 / 227$ & 42 \\
Allergic to pet* & $88 / 227$ & 39 \\
Allergic to pollen* & $52 / 227$ & 23
\end{tabular}

\section{Home characteristics during survey}

Carpeted bedroom floor

Carpeted living-room floor

$128 / 228$

$159 / 228$

$144 / 228$

$124 / 224$

Smoking inmates

$34 / 228$

56

70

63

55

Unvented water heater

\section{Allergen avoidance measures ${ }^{\dagger}$}

Moved to another house

$28 / 218$

$77 / 227$

$58 / 227$

$27 / 227$

New floor cover in living-room

New mattress

$66 / 227$

$55 / 228$

Removed pets

24

*: allergy diagnosed by a physician in the past; **: mammals and/or birds; ; for child's respiratory health.

(33/58), carpeted floors; new bedroom floors were found to be carpeted in only $25 \%$ of the cases (19/77). In all other cases, carpets had been replaced by hard floors. In table 2, the health outcome variables in the groups of children allergic and non-allergic to house dust are presented. The allergic subjects experienced more asthmatic symptoms and used more medication. There was no significant difference in PV.

Table 2. - Mean values and standard errors of the health outcome variables in two subgroups, classified according to reported allergy for house dust

\begin{tabular}{|c|c|c|c|c|}
\hline \multirow[b]{2}{*}{ Peak flow variability } & \multicolumn{2}{|c|}{$\begin{array}{c}\text { Allergic } \\
\mathrm{n}=95\end{array}$} & \multicolumn{2}{|c|}{$\begin{array}{c}\text { Not allergic } \\
\mathrm{n}=132\end{array}$} \\
\hline & 0.13 & $(0.007)$ & 0.12 & $(0.006)$ \\
\hline Cough & & & & \\
\hline $\begin{array}{l}\text { Woken up with } \\
\text { respiratory symptoms }\end{array}$ & 0.16 & $(0.029)$ & 0.11 & $(0.01)$ \\
\hline s of breath & 0.29 & $(0.03$ & 0.20 & \\
\hline Wheezin & 0.19 & $(0.030) *$ & 0.11 & $(0.020)$ \\
\hline $\begin{array}{l}\text { Attacks of shortness of } \\
\text { breath with wheezing }\end{array}$ & 0.069 & $(0.018)^{*}$ & 0.027 & $(0.008)$ \\
\hline Bronchodilators & 0.68 & & 0.34 & \\
\hline Maintenance medication & 1.77 & $(0.28) * *$ & 0.55 & $(0.12)$ \\
\hline
\end{tabular}

: allergy diagnosed by a physician in the past; \#: $p<0.10$; $*: \mathrm{p}<0.05 ; * *: \mathrm{p}<0.01$ (for difference between allergic and not allergic).

Der $p$ I concentrations in bedroom floor dust ranged from $104-60,527 \mathrm{ng} \cdot \mathrm{g}^{-1}$. The geometric mean was significantly higher in dust collected from carpeted floors $\left(2,077 \mathrm{ng} \cdot \mathrm{g}^{-1}\right)$ than in dust collected from smooth floors $\left(652 \mathrm{ng} \cdot \mathrm{g}^{-1}\right)$.

The health outcome variables were positively related with PV and cough, except the intake of maintenance medication which was slightly negatively related.

As many parents were found to have changed the bedroom floor cover from carpet to hard floors in the past, we decided to analyse the data separately for children with hard floors $(n=100)$ and carpeted floors $(n=128)$ in their bedrooms respectively. Bivariate regression analysis with potential confounders showed that age, area and presence of an unvented water heater in the house were

Table 3. - Linear regression models for health outcome variables with In of Der $p$ I level in bedroom floor dust, standardized for age, area and presence of unvented water heater; coefficients denote difference in health outcome variable associated with a difference in Der $p$ I exposure of $8,000 \mathrm{ng} \cdot \mathrm{g}^{-1}\left(10,000 \mathrm{ng} \cdot \mathrm{g}^{-1} \mathrm{compared}\right.$ to $\left.2,000 \mathrm{ng} \cdot \mathrm{g}^{-1}\right)$

\begin{tabular}{|c|c|c|c|c|c|c|}
\hline \multirow[b]{2}{*}{ Peak flow variability } & \multicolumn{2}{|c|}{$\begin{array}{l}\text { All subjects } \\
n=128\end{array}$} & \multicolumn{2}{|c|}{$\begin{array}{l}\text { Allergic to house dust }{ }^{\dagger} \\
n=39\end{array}$} & \multicolumn{2}{|c|}{$\begin{array}{l}\text { Not allergic to house dust } \\
\qquad \mathrm{n}=88\end{array}$} \\
\hline & 0.017 & $\begin{array}{l}(-0.006,0.027)^{*} \\
(+14 \%)\end{array}$ & 0.022 & $\begin{array}{l}(-0.003,0.047)^{\#} \\
(+16 \%)\end{array}$ & 0.012 & $\begin{array}{l}(-0.000,0.024)^{\#} \\
(+10 \%)\end{array}$ \\
\hline Cough & 0.037 & $\begin{array}{l}(-0.042,0.116) \\
(+7 \%)\end{array}$ & 0.053 & $\begin{array}{l}(-0.102,0.208) \\
(+10 \%)\end{array}$ & 0.013 & $\begin{array}{l}(-0.083,0.109) \\
(+3 \%)\end{array}$ \\
\hline $\begin{array}{l}\text { Woken up with } \\
\text { respiratory symptoms }\end{array}$ & 0.025 & $\begin{aligned} &(-0.008,0.58) \\
&(+23 \%)\end{aligned}$ & 0.061 & $\begin{array}{l}(-0.015,0.137) \\
(+49 \%)\end{array}$ & 0.014 & $\begin{array}{l}(-0.024,0.52) \\
(+13 \%)\end{array}$ \\
\hline Shortness of breath & 0.062 & $\begin{array}{l}(0.003,0.121)^{*} \\
(+25 \%)\end{array}$ & 0.046 & $\begin{array}{l}(-0.120,0.212) \\
(+12 \%)\end{array}$ & 0.042 & $\begin{array}{l}(-0.013,0.098) \\
(+22 \%)\end{array}$ \\
\hline Wheezing & 0.039 & $\begin{array}{l}(-0.006,0.083)^{\#} \\
(+29 \%)\end{array}$ & 0.059 & $\begin{array}{ll}(-0.053, & 0.170) \\
(+30 \%) & \end{array}$ & 0.031 & $\begin{array}{l}(-0.016,0.078) \\
(+29 \%)\end{array}$ \\
\hline $\begin{array}{l}\text { Attacks of shortness } \\
\text { of breath with wheezing }\end{array}$ & 0.021 & $\begin{array}{l}(-0.001,0.043)^{\#} \\
(+50 \%)\end{array}$ & 0.005 & $\begin{array}{l}(-0.059,0.070) \\
(+7 \%)\end{array}$ & 0.026 & $\begin{array}{l}(0.007,0.046)^{*} \\
(+93 \%)\end{array}$ \\
\hline Bronchodilators & 0.098 & $\begin{array}{l}(-0.080,0.275) \\
(+25 \%)\end{array}$ & 0.164 & $\begin{array}{l}(-0.262,0.590) \\
(+26 \%)\end{array}$ & -0.029 & $\begin{array}{l}(-0.220,0.162) \\
(-10 \%)\end{array}$ \\
\hline Maintenance drugs & -0.149 & $\begin{array}{l}(-0.443,0.145) \\
(-18 \%)\end{array}$ & -0.509 & $\begin{array}{l}(-1.23,0.207) \\
(-34 \%)\end{array}$ & -0.156 & $\begin{array}{l}(-0.450,0.138) \\
(-30 \%)\end{array}$ \\
\hline
\end{tabular}

Results are mean (95\% confidence interval). \% in brackets below are parameter estimate divided by mean of dependent variable, indicating the change (in \%) of the dependent variable for a change in the Der $p$ I level in bedroom floor dust from 2,000 to $10,000 \mathrm{ng} \cdot \mathrm{g}^{-1}$. ${ }^{+}$: allergy diagnosed by physician in the past. $\#$ : $\mathrm{p}<0.10$; *: $\mathrm{p}<0.05$ (for regression coefficient). 
significantly related to the means of one or more of the health outcome variables. Multivariate regression models were used to adjust for these variables. The results of the calculations for children with hard floors in their bedrooms showed that, in this group, there was no relationship between Der $p$ I exposure and any of the health outcomes. All coefficients were close to zero, some were negative and some positive. For children with carpeted floors in their bedrooms, the results were entirely different. Regression coefficients were positive for all health outcome variables with the exception of the use of maintenance medication. Coefficients for peak flow variability, shortness of breath, wheeze and attacks of shortness of breath were significantly different from zero (table 3 ). Coefficients were expressed in estimated percentage change from the population mean associated with a change in Der $p$ I concentration from 2,000 to $10,000 \mathrm{ng} \cdot \mathrm{g}^{-1}$. Peak flow variability was increased by $14 \%$, shortness of breath by $25 \%$, wheeze by $29 \%$ and attacks of shortness of breath with wheeze by $50 \%$.

Because we expected effects to concentrate in dust mite allergic children, we divided the population in children with doctor-diagnosed house dust allergy and children without doctor-diagnosed house dust allergy on the
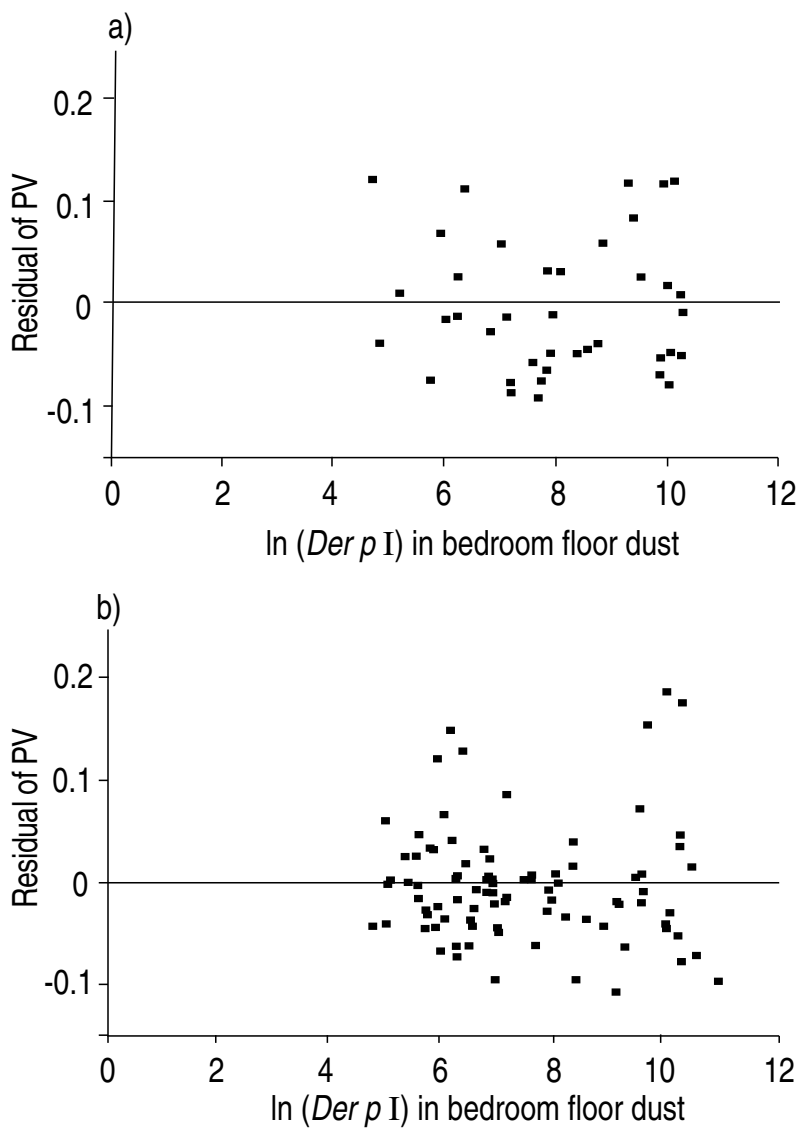

Fig. 1. - Residual scatterplots of peak flow variability vs. $\ln \operatorname{Der} p$ I concentration in bedroom floor dust in subjects with carpeted bedroom floors, subdivided according to reported allergy to house dust. a): subjects allergic to house dust $(\mathrm{n}=39) ; \mathrm{b})$ : subjects not allergic to house dust $(\mathrm{n}=88)$ basis of the questionnaire. For one subject, data were missing. Of the remaining 127 children with carpeted bedroom floors, 39 were reported to be allergic to house dust, whereas 88 were not. Table 3 shows the regression coefficients and estimated \% change in health outcome variables for total group and also the two sub-groups. Coefficients for all health outcome variables except attacks of shortness of breath were higher in the allergic population compared to the non-allergic population. Figure 1 shows plots of the adjusted relationship of peak flow variability with $\operatorname{Der} p$ I exposure in the two groups.

Figure 1 shows the scatterplots associated with the results reported in Table 3 . In order to investigate the threshold level Der $p \mathrm{I}$ at which PV is increased, we

\section{Odds ratio}

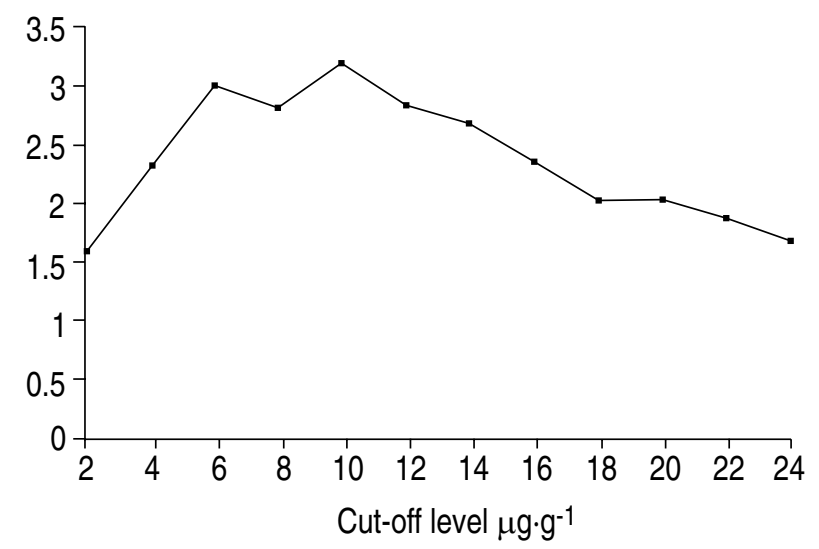

Fig. 2. - Odds ratios for high peak flow variability*, with different cut-off levels of Der $p$ I in bedroom floor dust; subjects with carpeted bedroom floors $(n=128)$. Odds ratios were statistically significant $(\mathrm{p}<0.05)$ for all cut-off levels in the range from 4,000 to $14,000 \mathrm{ng} \cdot \mathrm{g}^{-1}\left(4-14 \mu \mathrm{g} \cdot \mathrm{g}^{-1}\right)$. *: upper quartile of distribution $(0.145)$.

compared Der $p$ I exposure between children with PV values over 0.145 , the 75 th percentile, to children with PV values below 0.145 . We classified Der $p$ I exposure as "high" or "low" using a number of different cut-off points. The results for subjects with carpeted bedroom floors $(n=128)$ are shown in figure 2. Statistically significant odds ratios $(\mathrm{p}<0.05)$ were found for all cut-off points from 4,000 to $14,000 \mathrm{ng} \cdot \mathrm{g}^{-1}$.

\section{Discussion}

The subjects in this study were, on average, less severely asthmatic than in other studies [4, 5, 13]. Fifty eight percent had doctor-diagnosed asthma and $42 \%$ were allergic to house dust (table 1). Nevertheless, in a fairly large proportion of homes, allergen avoidance measures had been taken in the past. In another study that we conducted in homes of asthmatic children from an outpatient clinic [13], slightly more allergen avoidance measures had been taken, compared to the population described in this paper. In homes of symptom free children, we found a zero frequency of allergen avoidance measures [16]. 
In this study, house dust allergy was assessed by questionnaire. The same questionnaire was used in a casecontrol study on home dampness and respiratory disease in children [17], and in this study, specific serum immunoglobulin E (IgE) for house dust mite was measured. Using the same case definition as in our study, the sensitivity of the question regarding house dust allergy was found to be $66 \%$, and the specificity $96 \%$ when compared to house dust mite allergy, defined as radioammunosorbant test (RAST) class $\geq 1$. This suggests that there were probably very few non-allergic children in the group classified as "allergic" on the basis of the questionnaire. However, among those classified as "nonallergic" by the questionnaire, there were probably several with dust mite allergy, and this may explain why the relationship between Der $p$ I exposure and health outcomes was not absent in this group.

Der $p$ I levels in dust from carpeted floors were much higher than in dust from hard floors. This confirms the results of other studies $[13,16]$. The Der $p$ I levels were comparable to the results reported previously [17], but were higher than levels found in homes of more severely asthmatic children, both in smooth floors and in carpeted floors [13]. Because dust mite allergen levels on hard floors were so low, and because several of the more severely asthmatic children had hard floors in their bedrooms as a result of allergen avoidance measures, we were only able to analyse the relationship between dust mite allergen exposure and health outcomes in the children with carpeted bedroom floors. In this group, there were clear positive relationships between dust mite allergen exposure and peak flow variability, shortness of breath, wheeze and attacks of shortness of breath with wheezing.

The positive correlations between PV and respiratory symptoms indicate that measuring PEF and calculating $\mathrm{PV}$ provides an objective indicator for symptoms. Intake of maintenance medication was negatively correlated with PV. This may be due to the fact that these medicines are required to prevent acute symptoms and asthma attacks. Bronchodilators are mostly used to reduce asthmatic attacks (shortness of breath, wheezing). This explains the positive relations between use of bronchodilators and symptoms/PV.

In a small study among 98 more severely asthmatic children, Zock et al. [13] found no association of PV with the Der $p$ I level in bedroom floor dust, whereas there was an association with the Der $p$ I level in mattress dust. Only $36 \%$ of the children had a textile floor cover in the bedroom as opposed to $56 \%$ in this study. We did not sample mattress dust in our study; in the study by Zock et al. [13] the correlation between $\operatorname{Der} p$ I levels in dust collected from the 35 carpeted bedroom floors and in mattress dust was 0.72 , and mattress levels were only slightly higher than levels found in dust from carpeted floors $\left(2,753 \mathrm{vs} 1,663 \mathrm{ng} \cdot \mathrm{g}^{-1}\right.$ respectively, geometric means). In another study conducted in The Netherlands by our group [17] in which comparable methods for dust collection and analysis were used, the Pearson correlation coefficient between the $\ln$ (Der $p$ I content) in dust collected from 370 carpeted bedroom floors and in mattress dust was 0.65 , and mattress levels were again slightly higher than levels found in dust from carpeted floors $\left(5,317\right.$ vs $3,558 \mathrm{ng} \cdot \mathrm{g}^{-1}$ respectively, geometric means). It is, therefore, reasonable to expect that relationships between health outcomes and Der $p$ I exposure will be found for both bedroom floor dust and mattress dust when a reasonable number of bedrooms with carpeted floors are included.

Our analysis of different cut-off levels indicates that the suggested threshold level of $10,000 \mathrm{ng} \cdot \mathrm{g}^{-1}$ of settled dust as a risk factor for acute asthma may be too high (fig 2). Even in the relatively small number of children we studied, significant relationships between $\operatorname{Der} p$ I exposure and peak flow variability were found at cut-off levels down to $4,000 \mathrm{ng} \cdot \mathrm{g}^{-1}$. Allergen levels in mattress dust might be somewhat higher, but in view of the results presented earlier from studies conducted by our laboratory $[13,17]$, it is clear that the difference is probably less than a factor of 1.5. It seems likely that increased peak flow variability and symptoms can be found at even lower levels of exposure in more severely asthmatic children.

In conclusion, exposure to Der $p$ I found in dust from carpeted bedroom floors appears to increase the severity of asthma in children with a history of asthmatic symptoms.

Acknowledgements: We wish to thank the Dutch Asthma Foundation for financial support. Further, we are grateful to M. Boswijk, M. Koole, J. Schuit, F. Vergeest, F. de Waart and E. Wartena for their help, and of course to the children and their parents for their co-operation.

\section{References}

1. Sporik R, Holgate ST, Platts-Mills TAE, Cogswell JJ. Exposure to house dust mite allergen (Der $p$ I) and the developement of asthma in childhood. New Engl J Med 1990; 323: 502-507.

2. Sporik R, Chapman MD, Platts-Mills TAE. House dust mite exposure as a cause of asthma. Clin Exp Allergy 1992; 22; 897-906.

3. World Health Organization. Dust mite allergens and asthma: a worldwide problem. International Workshop Report. Bull World Health Org 1988; 66: 769-780.

4. Lau S, Falkenhorst G, Weber A, Werthmann I, Lind P, Buettner-Goetz P, Wahn U. High mite-allergen exposure increases the risk of sensitization in atopic children and young adults. J Allergy Clin Immunol 1989; 84: 718-725.

5. Price JA, Pollock I, Little SA, Longbottom JL, Warner JO. Measurement of airborne mite antigen in homes of asthmatic children. Lancet 1990; 336: 895-897.

6. Voorhorst R, Spieksma FThM, Varekamp H, Leupen MJ, Lyklema AW. The house dust mite (Dermatophagoides pteronyssinus) and the allergen it produces: Identity with the house dust allergen. J Allergy 1967; 39: 325339.

7. Lind P. Enzyme-Linked Immunosorbent Assay for determination of major excrement allergens of house dust mite species D. pteronyssinus, D. farinae and D. microseras. Allergy 1986; 41: 442-451.

8. Tovey ER, Chapman MD, Wells CW, Platts-Mills TAE. 
The distribution of dust mite allergen in houses of patients with asthma. Am Rev Respir Dis 1981; 124: 630-635.

9. Wood RA, Eggleston PA, Lind P, et al. Antigenic analysis of household dust samples. Am Rev Resp Dis 1988; 137: 358-363.

10. Schwartz B, Lind P, Løwenstein H. Level of indoor allergens in dust from houses of allergic and nonallergic individuals. Int Archs Allergy Appl Immun 1987; 82: 447-449.

11. Korsgaard J. Mite asthma and residency, a case-control study on the impact of exposure to house dust mites in dwellings. Am Rev Resp Dis 1983; 128: 231-235.

12. Vervloet D, Charpin D, Haddi E et al. Medication requirements and house dust mite exposure in mite-sensitive asthmatics. Allergy 1991; 46: 554-558.

13. Zock JP, Brunekreef B, Voûte PD, Hazebroek-Kampschreur AAJM, Roosjen CW, de Jongste JC. Het verband tussen vloerbedekking op basisscholen en acute luchtwegk- lachten, medicijngebruik en piekstroomvariatie van kinderen met astma. (In Dutch; with a summary in English). $T$ Soc Gezondheidsz 1993; 71: 243-250.

14. Quackenboss JJ, Lebowitz MD, Krzyzanowski M. The normal range of diurnal changes in peak expiratory flow rates. Am Rev Resp Dis 1991; 143: 323-330.

15. SAS Institute Inc. SAS User's Guide, Version 6, Fourth Edition, Cary, NC: SAS Institute Inc., 1989.

16. Verhoeff AP, Strien RT van, Brunekreef B, Wijnen JH van. Reported frequency of allergen avoidance measures in the homes of children with chronic respiratory symptoms and asthma. Am Rev Resp Dis 1992, 145: A533 (abstract).

17. Brunekreef B, Verhoeff AP, Strien RT van, Wijnen JH van. The role of sensitization on dust mites and moulds in explaining the relationship between home dampness and childhood respiratory symptoms. Proceedings 6th International Conference on Indoor Air Quality and Climate, Helsinki, July 4-8 1993, Vol I, 153-8. 